\title{
A garden experiment revisited: inter-generational change in environmental perception and management of the Maya Lowlands, Guatemala
}

\author{
Olivier le Guen Centro de Investigaciones y Estudios Superiores \\ en Antropología Social (CIESAS) \\ Rumen Iliev Northwestern University \\ XIMENa Lo Is University of Michigan \\ Scot т A т R n Centre National de la Recherche Scientifique, \\ Institut Jean Nicod, and ARTIS Research \\ Douglas L. Medin Northwestern University
}

\begin{abstract}
This study reports ethnographic and experimental analyses of inter-generational changes in native Itza' Maya and immigrant Ladino populations of Guatemala's Petén rainforest concerning understanding of ecological relationships between plants, animals, and humans, and the perceived role of forest spirits in sustaining these relationships. We find dramatic changes in understanding ecological relationships and the perceived role of forest spirits. Itza' Maya conceptions of forest spirits (arux) are now more often confounded with Ladino spirits (duendes), with Itza' spirits no longer reliably serving as forest guardians. These changes correlate with a shift in personal values regarding the forest, away from concern with ecologically central trees and towards monetary incentives. More generally, we describe how economic, demographic, and social changes relate to the loss of a system of beliefs and behaviours that once promoted sustainable agro-forestry practices. These changes coincide with open access to common pool resources.
\end{abstract}

In this study we describe an ongoing research project on how different groups of agro-foresters in the lowland rainforest of Guatemala deal with a resource dilemma involving the forest itself. Using ethnographic and experimental methods we describe inter-generational changes in Itza' Maya and Ladino understandings of ecological relationships between plants, animals, and humans, and the perceived role of forest spirits in sustaining these relationships.

While dealing with the conception of environment, this study also contributes to the perennial debate of nature versus culture. The subfield of ecological anthropology or French anthropologie de la nature is mainly interested in understanding the concept of nature as well as people's relation to nature. In recent years, ecological anthropology has been especially concerned theoretically and practically with environment policies, 
questioning how different cultures can (or should) manage their environmental resources (Charnley \& Durham 2010; Latour 2004; Moran 2007; Spoon 2012; Vayda 2009; Viveiros de Castro 1992; 2004).

However, if many studies have focused on how 'nature' is conceptualized in various cultures, few have criticized the very concept of nature and proposed some alternative to it. Among the most recent and significant contribution is the work of Descola (2011; 2013; but see also Gellner 1963; Ingold 2010), who classifies societies into various groups according to their relation to nature and the supernatural agents that inhabit them. Instead of simply opposing Western and non-Western cultures, he sorts them in terms of four types of relation: (1) naturalism, which opposes nature to culture; (2) animism, where human and nonhuman share the same ontology but have different physical properties; (3) totemism, where animals and supernatural entities share physical as well as moral qualities because of their common totemic ancestry; and (4) analogism, where every element in the world is different, which imposes a need to establish relationships between them that uses a universal human preference for analogical processes (Lévi-Strauss 1962; Vosniadou \& Ortony 1989). Central American cultures are good examples of the last category. Although Descola's contribution is helpful from a general comparative point of view, more local descriptions are still needed to establish more precisely people's relationships to nature and its supernatural agents, especially in the case of analogism-type societies. This article aims to do so by focusing on the evolution of people's relation to the environment.

Our intent in this article is to describe people's relation to natural forces and to measure them to see whether or not there is strong support for cultural change, not only in material culture and behaviours but also in mental representations.

This study follows previous work on knowledge change (mainly knowledge loss) in various cultural groups around the world. In particular, we follow Atran and Medin's work (2008) on folkbiological reasoning and ecological management. They find a base of universal cognitive processes that includes a taxonomic parsing and ranking of biological species into higher-order and lower-order groups (Berlin 1992), which enables systematic inferences concerning the relative distribution of biological properties among species (Atran 1995, 1998); however, cultural differences in understanding of nature are associated with significant differences in environmental decision-making as well as intergroup conflict and stereotyping stemming from these differences.

In attempting to understand but also to measure people's relationships and knowledge of nature and supernatural beings, we draw from the fields of cross-cultural psychology and cognitive anthropology. Anthropologists have advocated and demonstrated the feasibility and the benefit of a multidisciplinary approach (see Beller, Bender \& Medin 2012; Bender, Beller \& Medin 2012; Cohen 2010). The combination of anthropological and psychological approaches has been particularly fruitful for the study of religious beliefs. In trying to provide a naturalistic approach to religion, cognitive theorists of religion (Atran \& Henrich 2010; Boyer 1996; Whitehouse \& Laidlaw 2007) have claimed that believing in gods (or, more generally, supernatural entities) is a readily elicited by-product of naturally selected aspects of the human mind that functionally evolved for other purposes. These include a universal Theory of Mind (ToM), which allows for communication between human beings based on implicit assumptions about other people's internal mental representations (Sperber \& Wilson 2004; Whitten 1991). Anthropologists and psychologists have long argued that 
this process also applies to other types of interlocutors, in particular supernatural entities (Frazer 1922; James 1905). Goody (1995), for instance, considers that prayer is essentially constructed and understood as a dialogue between human and supernatural parties (she gives examples of prayers in the Judaeo-Christian but also the Buddhist tradition). More recent anthropological and psychological studies indicate that animism and non-material anthropomorphic agents cannot adequately be described simply as parts of a failed epistemology viewed from a modernist perspective, but function within a cultural context as ideas that help to regulate social and environmental practices (Bird-David 1999; Knight, Sousa, Barrett \& Atran 2004). The field experiments proposed below are based on the idea that people have representation of others' mental states and desires, even those of nonhuman agents. We aim to show that these representations of interactions between humans, supernatural agents, and nonhuman biological species reliably reveal how people understand and manage their environment.

Our project began over two decades ago and is still evolving (see Atran, Lois \& Ucan Ek' 2004; Atran \& Medin 2008; Atran, Medin \& Ross, 2004; Atran et al. 1999; 2002). The overall focus is on the role of mental models ${ }^{1}$ of the forest and sacred values in sustainable agro-forestry. This follow-up study was conducted among the Itza' Maya, indigenous inhabitants of the Petén forest in Guatemala, and settler Ladinos, who have immigrated to this area over the past thirty to forty years. As we shall see, within the space of a single generation, socio-economic, environmental, and linguistic changes have had a dramatic impact on mental models of the forest and on Itza' Maya cosmology.

First, we present our previous findings concerning older Maya and Ladino cosmology, focusing on the role of supernatural agents (guardian spirits of the forest). Next, we offer an updated survey of the current linguistic, environmental, demographic, and religious situation in Petén. Then, we report the results of studies conducted among younger Itza' and Ladino generations. Finally, we examine the link between the evolution of the mental models of the forest and sacred values in relation to changes in Maya cosmology.

\section{Previous research}

People's understanding of nature affects how they act on it (Atran \& Medin 2008). Previously, we assessed mental models and environmental management practices of three groups of milperos (farmers) who practise slash-and-burn agriculture in the rainforest of Petén (Atran, Lois \& Ucan Ek' 2004; Atran et al. 2002; Atran, Medin \& Ross 2005): native Itza' Maya from the municipality of San José; immigrant Ladinos from the adjacent community of La Nueva San José; and immigrant Q'eqchi' Maya from the hamlet of Corozal 18 kilometres away. In the present study, we restrict our attention to the Itza' Maya and Ladino samples.

The groups in the previous study did not differ in age, family size, land available for cultivation, or median family income. In many cases, farmer's milpas (farming plots) were adjacent and the groups did not differ in the quality of land that they cultivated under usufruct. Itza' have been indigenous to this part of Guatemala since well before the Spanish conquest, and the Ladinos migrated in thirty to forty years ago. Individuals from both groups have extensive experience with slash-and-burn agriculture in Petén's lowland rainforest. 
Although both groups practise slash-and-burn farming, previous studies of soils, forest regeneration, and crop diversity show clearly differences in practices, with corresponding consequences for the land. Ladinos typically use a plot for two years and intermittently leave trees within and between plots. Itza' use plots for two to three years or in some cases considerably longer. They regularly ring plots with trees, clear firebreaks around fruit trees and other valuable trees, and change plots in a noncontiguous fashion. For the Itza', this is an explicit strategy to encourage forest regeneration.

The Ladinos clear more land and leave land fallow for a shorter period than the Itza' do. The Itza' also grow a wider range of crops, and differ from Ladinos in doing a second weeding several weeks after the spring burn, leaving the weeds as mulch. In addition, crop and tree counts reveal that Itza' plant a more diverse set of crops and have greater tree diversity and tree cover. In short, reported practices correspond to direct ecological assessments.

To examine how these groups think about the forest, Atran et al. (2002) initially asked members of each group to name the most important plants and animals for the forest. There was substantial agreement across groups. Twenty-eight important plants and twenty-nine important animals were selected, ${ }^{2}$ and Itza' and Ladinos participants were asked how each plant and animal affected every other plant and animal, in effect assessing how participants conceptualized ecological relations. Regarding how plants affect animals, Ladino and Itza' informants displayed very similar profiles. Nominated relations were almost exclusively plants helping animals (by providing food, shelter, shade, etc.). Furthermore, Ladino and Itza' informants showed high agreement on which plants help which animals.

Perceptions of how animals affect plants, however, produced large differences. Ladinos and Itza' generally agreed on ways in which specific animals hurt specific plants; yet, strikingly, Ladinos tended to deny that animals can help plants. In contrast, Itza' reported as many helping as hurting relations and four times as many helping relations as Ladinos. In many cases, Ladinos and Itza' appeared to be drawing the opposite conclusions from the same observations. For example, Ladinos tended to report that birds hurt the fruit trees by digesting their seeds. Itza' had a more nuanced interpretation: they said that if the seed coat is soft, eating the seeds destroys them, whereas if the seed coat is hard, then digestion plus fertilization (from excrement) helps the seed to germinate. Overall, one could characterize the ecological models of plantanimal interactions as follows: (1) Ladinos had a hierarchical model where plants help animals and animals help people but did not conceptualize animals as helping plants; and (2) Itza' had a rich, reciprocal ecological model where plants help animals and animals help plants.

Later, we asked informants from each group how they used various plants and whether people of their own community helped, hurt, or had no effect on the twentyeight plants (Atran et al. 1999; 2002). Ladinos said they both help and hurt plants, with the best predictor of whether helping or hurting being economic importance or cash value. In contrast, Itza' said that they hurt only a few plants but protect most other plants. Two independent factors predict the degree to which a plant is protected: (1) total number of uses Itza' had for the plant; and (2) ecological centrality (i.e. protecting species that are involved in many plant-animal interactions).

Evidence indicates that Itza' protect what they say they protect. Impact ratings reliably predicted the absolute and relative numbers of different kinds of trees that we 
found in surveys of Itza' farmers' parcels. In sum, the Atran et al. data (Atran, Lois \& Ucan Ek' 2004; Atran et al. 1999; 2002; 2005) indicate that the one group which operates sustainably, the Itza' Maya, have a rich ecological model. Furthermore, Itza' apparently use that understanding in their interactions with the forest, protecting species that are more ecologically central. But we also found reliable evidence of a spiritual component to their understanding of the forest, to which we now turn before updating our assessment with a younger generation (25-45 years old) of Itza' and Ladinos.

\section{Cosmology and the Maya relationship to the environment}

Itza' Maya cosmology resembles that of other Maya groups with whom they share a linguistic heritage: the Yucatec of Mexico and Belize, the Mopan of Guatemala and Belize, and the Lacandon of Mexico; their connection with the environment is conceptualized as a three-term relationship, which includes the mediation of forest spirits. The Maya landscape is populated by 'masters of spaces' (yum-il), who informants claim were placed at the creation of the Earth by God. The masters of space might be better described as 'guardian spirits': their duty is 'to protect' a particular, more or less delimited, space as well as the living things that inhabit or pass into it; thus, the generic Itza' Maya term aj känan(-oo'), 'the protector(s)'.

To exploit a particular space, or the resources within it, Maya assume they have a duty 'to pay' (b'o'-t-ik) the guardian spirits of the space for human activities, such as plant collecting, hunting game, seasonal agriculture, and even more permanent activities like house construction. Payment to guardian spirits is made through ritualized food offerings. Non-respect for the rules of space use, or violation of them (nonpayment or abusive exploitation), leads to direct or indirect punishment by guardian spirits: for example, harming the person or his/her relatives. Usually the guardian spirits send some kind of illness whose cure requires a ritual payment to the right entity (Adams \& Rubel 1967).

The Itza' Maya pantheon traditionally involved several kinds of entities or spirits, although not all are considered guardian spirits of the forest. Some, including the Saint of the town (San José) and the Three Skulls (Tres kalab'eeras), share functions with guardian spirits, but their domain is limited to the town or its inhabitants. Itza' also identify other forest entities, such as the siren-like Ix Tabay or the frightful Sisimit, but do not recognize them as protectors of specific spaces. They are generally considered harmful, not only because they can entice people into disaster, but also because they are not attached to any particular space. ${ }^{3}$

The arux are the most important guardian spirits of the forest. Itza' refer to living kinds of the forest as b'a'al=che'(-oo'), a term usually translated as 'animals', but literally 'things of the forest'. In Itza', this designation includes the category 'animals' as well as the spirits of the forest (guardian spirits and evil spirits). This categorization is still transparent among younger Spanish-speaking Itza', who sometimes refer to forest spirits as animalitos, 'little animals'. Crucially, in Maya culture, in order to exploit forest resources, humans necessarily have to interact with supernatural entities, specifically the guardian spirits of space.

People of San José describe the appearance and habits of arux as guardian spirits who live in caves but move around in the forest and sometimes enter the town. An arux looks like a little man with a large hat often covering his eyes when he appears near villages and towns, but may have a much larger aspect in the forest. One cannot see an arux when it enters a house or sits on the limb of a tree, but only as it is walking away. 
Arux are hermaphrodites, with a tendency to fall in love with young men or women, sometimes pursuing them to the point of persecution. They are also known for kidnapping children, although the children are usually returned later.

When arux assume the role of guardian spirits of the forest (uyumil k'aax), they use a bag of tricks to test people's abilities to navigate and exercise self-control in the forest to prevent over-exploitation. But the arux are also helpers: if someone knows the right prayers, prays regularly, and shows respect, then the arux will lead a hunter to game or give the chiclero (chicle tree tapper) enough strength to collect a large amount of resin from the chicle tree (Manilkara chicle). The arux compel people to honour their particular 'contractual' obligations to the environment, such as collecting plants of a certain species without harming prospects for rapid replenishment of stock. In this sense, belief in arux is part of a broader set of social control norms that arguably represents the summary knowledge of a tradition of agro-forestry management stretching back for a millennium or more (Atran, Lois \& Ucan Ek' 2004; Atran et al. 2002).

Itza' Maya ritual life is closely linked to nature. Itza' rituals often involve culturally significant plants, such as copal and allspice. Like other Mesoamerican cultures, Itza' believe that spirits consume only ethereal aspects of ritual offerings. Thus, highly redolent copal smoke, from the burned resin, is a valuable kind of offering and has traditionally been used for a great many kinds of ritual events. Aromatic allspice is also considered highly agreeable to the spirits. The ceiba tree is likewise of particular importance for Itza' for its limbless trunk, and the lush green crown is associated with the Ix Tabay, a forest enchantress.

Ladinos also acknowledge the existence of some supernatural entities but, unlike the Itza', they play no apparent role in relations with the environment. The main functions of these Ladino supernatural entities relate to social issues and are more focused on social control than environment exploitation. Thus, entities like the duende (a counterpart of the Itza' arux) are merely tricksters. These spirits are not as well known among the younger generations, in part because of inroads by evangelical Protestantism, which condemns any belief in such spirits.

Some authors have noted the importance of religious practices in the management of natural resources, including for the Guatemalan setting (e.g. Katz 2000; Wilson 1995), and our previous work indicates that sacred values and beliefs in supernatural entities constitute a powerful and coherent system of representations that play a crucial role in the practice and transmission of ecological knowledge (Atran et al. 2002; 2005). In what follows, we show that a general degradation in these values and beliefs accompanies a corresponding degradation in ecologically valuable knowledge and practice.

\section{Cultural, linguistic, and ecological changes}

Since the initial work of Atran et al. (1999; 2002), which covers the period 1990-2000, a number of dramatic changes in the cultural and ecological landscape of Petén have occurred. We now offer an update of the situation (late 2008 to early 2013), informed by follow-up tasks and further ethnographic fieldwork.

In spite of revitalization efforts in the 199os, Itza' Maya is on the verge of extinction (Hofling 1996), with fewer than twenty fluent speakers. In the 1980s, there were still a number of Itza'-speakers, more than fifty, in addition to a number of passive speakers who rarely conversed in Maya. (For the most part, only those born before the rule of Guatemala's dictator General Jorge Ubico, who banned spoken Itza' in schools and 
other public venues in the 1930s, spoke Itza' as their native tongue.) There have been recent efforts to document and revitalize the Itza' language, mostly conducted by the Academia de Lenguas Mayas de San José. Still, no children are socialized in the Maya language and they are now entirely Spanish monolinguals. The significance of loss of a native language cannot be over-emphasized, for '[a] language is far more than just talking to each other. It's a repository of cultural wealth, history, tradition, group identity, a central part of what makes life worth living' (N. Chomsky to S. Atran, pers. comm., 24 March 2012).

Environmental change has been also very dramatic. After the Spanish conquest and the fall of the last Itza' kingdom in 1697, exploitation of the forest was carried out by small indigenous groups (mainly Mopan and Itza'), without apparent long-term detriment to forest ecology. Matters changed at the end of the nineteenth century with the exploitation of the resin of the chicle tree (or Chicozapote $=$ Manilkara chicle). North American companies hired local contractors to mobilize indigenous people to look for the 'white gold' resin used in the fabrication of chewing gum. The extractive economy built around the exploitation of chicle did not generate much development in Petén, nor did it affect traditional forms of agricultural practice (chicleros would go in the forest only during slow agricultural work periods). Although this activity attracted some outside populations to Petén (from Guatemala and Mexico), Schwartz notes that 'the chicle industry had a profound effect on individual lives, but it did not change the structure of the host society' (1990: 8). Nowadays, few Itza' collect chicle. Collapse of the chicle industry in the early 1970 s overlapped with Guatemalan governmental efforts to colonize the Petén region, considered until then 'an economic hinterland' (Schwartz 1987: 166).

In 1958, Petén was opened to 'colonization and development' and managed by a military-run governmental organization called FYDEP (Empresa Nacional de Fomento y Desarrollo Económico del Petén). In the 1990s, this was replaced by civilian-run CONAP (Consejo Nacional de Areas Protegidas) under a 'debt-for-nature' swap organized by the United States Agency for International Development. Petén was divided into three protected areas: (1) a zone of total conservation free from human intensive exploitation, situated to the north, and bordering Mexico (where national parks and biotopes are located); (2) a 'buffer zone', comprising a 20 kilometre belt running along the first zone's southern perimeter; and (3) a 'multiple use zone', representing 40 per cent of the total protected area. The town of San José is situated in the buffer zone.

Petén's population increased dramatically from 21,00o in the 1960 s to an estimated 500,000-1 million over the last decade (Grandia 2000; Schmidt 2010). Population make-up also changed; the Q'eqchi', an indigenous Maya group, have immigrated in large numbers from the highlands of Guatemala, along with Ladino populations from Guatemala (mostly from the southern departments) and El Salvador. Forms of forest exploitation also changed markedly. Slash-and-burn agriculture, which favours forest regeneration at least as traditionally practised by Itza', is in steep decline. Wealthy Ladino immigrants from the nearby towns of Santa Elena and Flores permanently clear forest to create pastureland for cattle-rearing and then hire the poorer, local Ladinos to care for the cattle. They also favour intensive large-scale extraction of precious woods over conservation, destroying wide swathes through the forest to extract tropical cedar (Cedrela odorata) and mahogany (Swietenia macrophylla) (Dugelby 1998; Schwartz 1987; 1990; Selleron 2004). These swathes then become access routes for new immigrant farmers and cattle ranchers. 
The Guatemalan civil war (1960-95), which brought death and destruction to many Highland Maya communities, had little direct impact on the central Petén Lowlands. Although our field team witnessed several military sweeps through the area and occasional guerrilla raids from the late 1970s to the early 1990s, these rarely involved the Itza' or sustained activity in nearby Ladino and creole (long-standing Spanish-speaking) communities. More recently, however, Petén has become an important transit region for drug-trafficking operations linking Colombia, Mexico, and the United States, with ever larger swathes of the rainforest being cleared for makeshift airfields and other drug-related clandestine operations (Contreras 2012; Schmidt 2010). Population growth and, increasingly, inaccessibility to forest lands because of illegal cattleranching and drug-trafficking have created severe problems for the indigenous people, and there is now a permanent police presence in San José itself. As in Colombia, laundered drug money has also helped to spawn economic investment and rapid urban development, with distributions of largesse to local officials and wider segments of the local population geared to ensure acquiescence and support.

Until recently, distribution of land was founded on family rights and community agreement, but it is now increasingly based on title rather than usufruct rights. Obtaining and holding title depends on availability of funds, which native folk often lack, and on administrative procedures that are often co-opted and turned to the advantage of outside interests. Relative to just a decade ago, there has been a sharp reduction in the number of men cultivating their agricultural plot (milpa) in San José. Interviews conducted post-autumn 2009 in San José counted twenty-three full-time milperos, among them thirteen from the younger generation (from 21 to 44 years old, 27 years old on average).

To track the distribution and flow of knowledge related to farming and forestry practices within and between the Itza' and Ladino communities, we collected social network data. We used a snowball method (Goodman 1961), asking informants to name seven people outside their household who were most important to their lives (social network), and the names of seven people they would go to for advice about the forest (expert network). Then we asked the same question to the first and seventh mentioned in each of the networks. The resultant networks were highly informative, reliable, and redundant with re-tests (Atran et al. 1999; 2002).

We recently collected new social network data with milperos. We asked about the ages and occupations of the people named and used these data to estimate the proportion of men engaged in different activities. When a person was mentioned more than once, and if there was disagreement about his occupation or age, we took the average of all referees. For example, if three informants said that person $X$ was a milpero whereas one did not, we assigned a .75 probability that $X$ was milpero. This yielded 301 distinct male subjects. One way to verify changes in the region is to see if occupations related to the forest are less popular among the younger generation. Our network data show that younger Itza' males are less likely to be milperos compared with older Itza' (44 per cent versus 77 per cent).

Even these estimates may be high: Itza' who still have milpas (farm plots) typically work their field only during the weekends and have other employment for primary income. Itza' elders also report that native Petenero maize is being replaced by hybrid seed, which produces greater yields (but which rots much faster). There is also a generational decrease in chicle activities: 36 per cent for older Itza' compared to 7 per cent for younger Itza' men. For younger versus older Ladinos, there is little change 
across generations in making milpa (70 per cent for younger versus 75 per cent for older).

Until now, the town of San José, unlike the neighbouring town of San Andrés, has managed to maintain relative ethnic homogeneity. A wave of Spanish-speaking Ladino immigrants came in the 1970 s and some asked permission to settle near San José, in a separate satellite town (aldea) about a kilometre away, called Nueva San José, or simply La Nueva. Q'eqchi' Maya immigrants formed their own village, the aldea of Corozal, located 18 kilometres from San José. Ladinos immigrated into the area as nuclear families from diverse parts of the country, whereas Q'echi' arrived in clusters of families and neighbours from the same highland home area. La Nueva continues to grow from newcomers, who are mainly Ladinos, but also other Maya from the Highlands of Guatemala (Q'eqchi', Kaqchikel, and K'iche').

Until the 1960s, Itza' Maya continued folk religious practices and nearly all the people of San José (97.9 per cent) were Itza' Maya. All were folk Catholics, syncretically perpetuating 'several old Maya practices and beliefs' (Reina \& Schwartz 1974: 167). These practices were of two kinds: individual rituals conducted in the forest and collective rituals conducted in the town. They were performed for agricultural purposes (e.g. the 'dinner-to-the-milpa' or primicias), to cure illnesses, or deal with death. During the second half of the twentieth century, these practices began to lose importance as the lack of ritual specialists became more pronounced (see Reina 1961). Folk Catholic ceremonies were conducted by a local Maya prioste (church helper), and were 'inherently connected with being a milpero and a San Joseño' (Reina \& Schwartz 1974: 169). But a new Catholic push began at the end of the 1950 in Petén with the arrival of missionaries who aimed to reorientate local people to the formal rules of Catholicism. From the 1970s onwards, Protestant evangelical movements began to increase their presence dramatically (most notably in the 1980s when General Ríos Montt, Guatemala's evangelical dictator, required the country's officials publicly to display loyalty to the evangelical creed lest they and the communities they came from be suspected of 'communist sympathies' and be dealt with accordingly). Today, God is a directly accessible entity who has an important role in social control and personal moral obligations. Ever since the death in 2004 of Don Domingo Chayax Suntecún, ${ }^{4}$ the last Maya ritual master, Catholic rituals have been managed by outside priests who no longer acknowledge the presence of forest spirits. The agro-forestry ritual practices that were important at the end of the twentieth century have now completely disappeared.

Evangelical Protestant ideology often tends to suppress local folk cosmology by banishing any kind of syncretistic belief, including worship of forest spirits (Steinberg 2002). The evangelical movement of the 1970 did not initially take hold in San José (Reina \& Schwartz 1974: 178-80), but there are now several churches in the town, although the majority of Itza' remain Catholic.

La Nueva is composed of a heterogeneous population of immigrants who, in absence of kin and cultural bindings, find new social and economic opportunities in evangelical churches (Garrard-Burnett 1998; Steinberg 2002; Willems 1967). The town counts several Protestant congregations and temples, which continue to expand as new settlers arrive.

Cultural and religious changes are correlated with an evolution in infrastructure development. Since 1959 and the opening of Petén colonization, roads and infrastructure have been continuously developing. The provincial capital of Flores is connected by a modern road to the national capital, Guatemala City, and to the Mexican border 
through Belize. Flores has an airport that facilitates mobility as well as national and international tourism. Previously, the main form of transportation from Flores to San José was by boat or by dirt road. In 2007, an asphalt road linked San José to San Benito, Santa Elena, and Flores, adjacent towns situated on the other side of the Lake Petén-Itza.

Easier access to Petén has favoured foreign tourism and 'eco-tourism'. The latter has compelled local authorities to attempt to protect some forest areas (mainly around archaeological sites) from exploitation by immigrants. Satellite imagery and field studies around archaeological areas show that the surrounding forest has been damaged, in some places extensively (Selleron 2004). In San José, the Bio-Itza' association aims to preserve bio-diversity through a combination of vigilance (forest guards), eco-tourism, language teaching and revitalization, and workshops and commercial activities that explain and support the sustainable use of local plants (Chayax Huex, Tzul Collí, Gomez Caal \& Gretzinger 1998). These local initiatives have been modestly supported by the international community, including the World Bank, and a pool of local and foreign NGOs (Brigadas Internacionales de Paz 2007). By early 2013, however, outside support had practically dried up as a consequence of dwindling international concern with directly promoting forest conservation in general, and preservation of the Maya biosphere in particular. With lack of means to employ forest guards or selectively harvest and transport sustainable forest products, predatory use and degradation of Bio-Itza' forest resources by outsiders now threaten the Itza' community's largest remaining forest reserves.

In sum, over the past decade or so there has been a precipitous decline in the knowledge and practice of long-standing cultural forms, loss of native language and religious ritual, and a marked degradation of the ecological balance owing to massive immigration, deforestation, and the closing off of tracts of land by clandestine ranchers and drug-traffickers. We now turn to how these changes translate into a loss of knowledge about the forest, especially the spiritually mediated understanding of the relationships and relevance of forest plants to people's lives.

\section{Studies of the present situation}

There is a body of research on traditional societies showing that the adoption of technology (even bicycles) and attending formal schools is associated with lessening knowledge of the natural world (Diamond \& Bishop 1999; Nabhan \& St Antoine 1993; Wester \& Yongvanit 1995; Zent 2001). We anticipated observing a similar loss of knowledge, and the main contribution of the present research is to provide a detailed look at specific changes in conceptions of the forest and the spiritual entities that inhabit it, rather than knowledge per se. Previous work shows that reduced contact with nature in developed countries leads to long-term devolution of biological knowledge (Atran \& Medin 2008), but changes in Petén give us the opportunity to look at evolving conceptions of the forest in a much shorter time-frame.

As noted earlier, members of Itza' and Ladinos communities believe in forest spirits: arux among the Itza', duende for Ladinos. Initially, we had assessed understandings of the role of the forest spirits by a plant species-ranking task. We asked informants to rank the importance of twenty-two of the twenty-eight species of plants from several distinct perspectives: for members of their own community, members of each of the other two communities, God, and the forest spirits or arux. 
In our earlier studies, we conducted interviews with Maya-speaking Itza' elders (averaging about 60 years old). To balance for age, we also interviewed older Ladinos. We checked if the members within a group agreed enough to make generalizations about their rankings. The Ladinos reached consensus on themselves, the Itza', and God, but not the forest spirits. ${ }^{5}$ Itza' elders showed an overall consensus on everything but God. The best predictor of how the Itza' said God would rank order the plants was the overall number of Itza' uses. The best predictors of how Itza' men believed the arux would rank plants were ecological centrality and combined uses.

Only the Itza' saw the arux as guardian forest spirits. Itza' consensus on supernatural forest preferences and priorities was a significant predictor of agro-forestry sustainability. This consensus about which species are most valuable and worthy of protection accords well with the anthropogenic character of the forest in the heyday of Classic Maya civilization 1,500 years ago (Atran et al. 2002). A plausible hypothesis is that spirit preferences represent a synthesis of experience accumulated over generations. Violations of spirit preferences can lead to accidents, falling ill, or worse. It matters little if the supernatural threat is real or not: if people believe in it, the threat of punishment becomes a real deterrent. Our research team has witnessed Itza' who have been bitten by deadly pit vipers refuse to be taken for anti-coagulant treatments that could save their limbs or lives, unless they first had a chance to venture into the forest to ask the spirits for guidance or forgiveness.

The arux are a very concrete entity for the Itza' and they ascribe them with explicit, concrete preferences. In the arux rankings, Itza' said that arux would give high rankings to the water vine and the allspice tree, describing how arux obtain water from the former and noting that arux especially like the tastes and smells of the latter. Arux were also said to value other fruit trees, such as ramón and ciricote.

In sum, mental models of the forest, values, and spirits affect the very conception of the Petén rainforest as a natural resource. In the Itza' view, the forest is not a passive resource waiting to be exploited, but rather an active player that is responsive to the behaviour of others. The import of the Itza' conception of the arux is that the forest itself has moral standing. In the present follow-up study, we reproduce Atran et al.'s ranking task but with younger adults (25-45 years old) from each group.

\section{Methods, participants, and procedure}

To address the possibility of generational differences in forest conceptions, we interviewed a younger sample of informants from the same Itza' and Ladino communities, often even from the same household or from the extended family of our older informants. Twelve Itza' (six women) and thirteen Ladinos (six women) participated, with each informant being interviewed separately. Previous cross-cultural research shows that even this restricted number of informants can suffice to establish cultural consensus provided that there are a sufficient number of rated items for each informant (Atran et al. 2005). The average age of the two samples was 34 and 31, respectively. The main sources of income reported were 'household' (casa) and 'agricultural work' (milpero) for Ladinos and 'casa' and 'other' (salaried jobs) for Itza'. The interviews were conducted in people's homes or at our research house.

For the first task, participants were asked to rank in importance a set of twenty-two plant species. The plants came almost exclusively from a larger sample of species we had used to assess ecological models. The list was designed to include plants with different degrees of importance and utility (see Table 2). First, participants were asked to rank 
order the plants from the list according to their own values and preferences. Then the cards were shuffled and participants were asked again to rank the plants to reflect God's valuations. Finally, preferences of the forest spirits (arux for the Itza' or duende for the Ladinos) were used as a ranking criterion. ${ }^{6}$

We used the Cultural Consensus Model (CCM) to assess within- and across-group agreement and within- and across-generation ranking agreement. The CCM is a factoranalytic method of modelling consensus that permits one to describe emergent cultural patterns that are derived statistically from measurements of individual cognitions and behaviours (Romney, Weller \& Batchelder 1986). ${ }^{7}$ We separated our participants into four groups: younger Itza', younger Ladinos, older Itza', and older Ladinos. The older Itza' and Ladino data are taken from the Atran et al. (2002) study. The results show dramatic changes in how Peteneros conceptualize the forest.

The CCM analyses are summarized in Table 1. One result is that the younger generation failed to show a reliable group consensus for any of the three main ranking tasks. First factor scores for younger Ladinos accounted for 23 to 33 per cent of the variance and the ratio of first to second factor scores ranged from 1.5 to 2.5, well short of a consensus. For younger Itza', first factor scores accounted for 25 to 35 per cent of the variance and the ratio of the first to second factor scores ranged from 1.o to 1.6. Combining the younger Itza' and Ladinos samples did nothing to increase either the variance accounted for by the first factor or the ratio of first to second factor scores.

Table 1. Variance explained by principal component analysis for each of the three value rankings.

\begin{tabular}{|c|c|c|c|c|c|c|}
\hline Rankings & Groups & $\begin{array}{l}\text { Factor } \\
1(\%)\end{array}$ & $\begin{array}{l}\text { Factor } \\
2(\%)\end{array}$ & $\begin{array}{l}\text { Factor } \\
3(\%)\end{array}$ & $\begin{array}{l}\text { Ratio } \\
\text { Factor } 1 / \\
\text { Factor } 2\end{array}$ & $\begin{array}{l}\text { Competence } \\
\text { difference }\end{array}$ \\
\hline \multicolumn{7}{|l|}{ Personal } \\
\hline & All four & 33 & 14 & 7 & 2.4 & \multirow{7}{*}{$\begin{array}{l}\text { n.s. } \\
\text { n.s. }\end{array}$} \\
\hline & Itza' old and Ladino old & 49 & 10 & 9 & 4.9 & \\
\hline & Itza' young and Ladino young & 26 & 16 & 9 & 1.6 & \\
\hline & Itza' old & 55 & 11 & 10 & 5.0 & \\
\hline & Ladino old & 49 & 15 & 11 & $3 \cdot 3$ & \\
\hline & Itza' young & 35 & 22 & 12 & 1.6 & \\
\hline & Ladino young & 23 & 15 & 13 & 1.5 & \\
\hline \multicolumn{7}{|l|}{ God } \\
\hline & All four & 25 & 12 & 8 & 2.1 & \multirow{7}{*}{$\begin{array}{l}\text { n.s. } \\
\text { n.s. }\end{array}$} \\
\hline & Itza' old and Ladino old & 31 & 15 & 10 & 2.1 & \\
\hline & Itza' young and Ladino young & 24 & 15 & 12 & 1.6 & \\
\hline & Itza' old & 34 & 19 & 11 & 1.8 & \\
\hline & Ladino old & 46 & 13 & 11 & 3.5 & \\
\hline & Itza' young & 27 & 19 & 16 & 1.4 & \\
\hline & Ladino young & 26 & 14 & 12 & 1.9 & \\
\hline \multicolumn{7}{|c|}{ Arux/duende } \\
\hline & All four & 26 & 23 & 9 & 1.1 & \multirow{7}{*}{$\begin{array}{l}\text { Itza' higher } \\
\text { n.s. }\end{array}$} \\
\hline & Itza' old and Ladino old & 41 & 13 & 8 & 3.2 & \\
\hline & Itza' young and Ladino young & 27 & 16 & 10 & 1.7 & \\
\hline & Itza' old & 54 & 13 & 6 & 4.2 & \\
\hline & Ladino old & 34 & 15 & 15 & 2.3 & \\
\hline & Itza' young & 25 & 24 & 12 & 1.0 & \\
\hline & Ladino young & 33 & 13 & 12 & 2.5 & \\
\hline
\end{tabular}


Finally, we examined the data for each group for within-gender consensus but did not find it. These observations are consistent with a generalized loss of knowledge.

These data sharply contrast with results from the older samples. For personal values, older Itza' (first factor $=55$ per cent of the variance, ratio of first to second factor $=5.0$ ) and older Ladinos (first factor $=49$ per cent of the variance, ratio of first to second factor $=3.3$ ) reach consensus. For God's rankings, older Ladinos show consensus (first factor $=46$ per cent of the variance, ratio of first to second factor $=3.5$ ) but not older Itza' (first factor $=34$ per cent of the variance, ratio of first to second factor $=1.8$ ). This pattern is reversed for ranking from the arux/duende perspective (older Itza', first factor $=54$ per cent of the variance, ratio of first to second factor $=4.2$; older Ladinos, first factor $=34$ per cent of the variance, ratio of first to second factor $=2.3$ ). If we combine the older Itza' and Ladino samples, there is overall consensus for personal values and for the arux/duende. For the latter, the older Itza' have reliably higher first factor scores than Ladinos $(p<.05)$. In a third analysis, we performed separate consensus analyses for our Itza' and Ladino samples, combining the data across generations. The combined samples fell short of consensus on each of the three rankings, further evidence for cross-generational differences. Overall, these analyses reveal a substantial loss of consensus both within and across groups from the older generation to the younger generation. The one exception is the rankings from God's perspective, where only older Ladinos show a consensus.

Consensus analysis represents a stringent criterion for agreement, and one can fail to arrive at an overall consensus but still observe consistency in rankings. The analysis of the three rankings for the four groups, using a Friedman two-way ANOVA, revealed significant effects for stimuli for all twelve rankings $(p s<.05)$. Rankings of the particular plants differed across generations for each of the groups. A profile analysis revealed that young Ladinos differed from older Ladinos on personal $(F(21,462)=2.51$, $p<.005)$, God $(F(21,462)=2.10, p<.005)$, and arux/duende $(F(21,462)=1.66, p<.05)$ rankings. The same three rankings also differed significantly between younger and older Itza' (personal $(F(21,525)=3.26, p<.001)$, $\operatorname{God}(F(21,525)=1.91, p<.001)$, and $\operatorname{arux}(F(21,525)=5.66, p<.001)$. In short, even though samples often did not meet the $\mathrm{CCM}$ consensus criteria, they agreed with each other enough to reveal robust effects of stimuli. In addition, there are clear generational shifts in rankings for each of the three perspectives for both groups. Table 2 summarizes the mean rankings for the plants for each of the groups.

\section{Generational changes in plant rankings}

Changing values about plants are manifest in Itza' personal rankings. Mahogany is primarily exploited today for cash value (although it also has other uses that range from traditional medicines, to canoes, shampoos, etc.). Despite the fact that it has been a major forestry export for a long time, older Itza' put it in the middle of their personal rankings (mean rank $=9.9$ ). Younger Itza' rank mahogany at the top (mean rank $=2.9$ ), suggesting an increasing role of market factors in personal values. A similar pattern is seen for Santa María and kanlol, which have some cash value but little ceremonial or ecological importance. In contrast, copal, whose resin is used in traditional Maya ceremonies as incense, has a higher personal ranking for older than for younger Itza'. Lower values for younger Itza' may reflect the partial replacement of Catholicism (fairly tolerant of a range of spiritual practices) by evangelical beliefs that condemn noncanonical practices. 


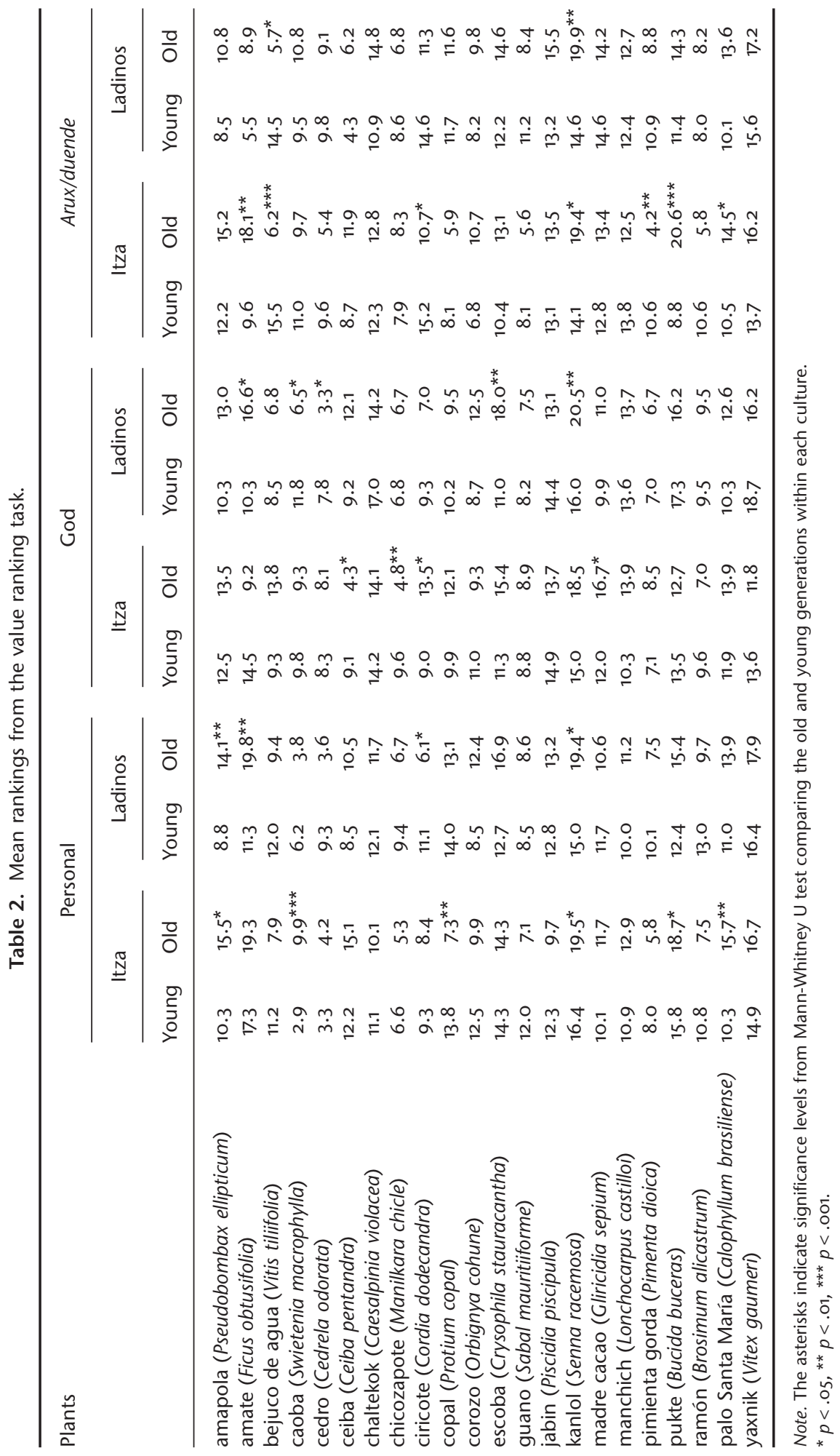

Journal of the Royal Anthropological Institute (N.S.) 19, 771-794

(C) Royal Anthropological Institute 2013 
If these generational changes reflect a loss of knowledge, then the regression towards the middle of the rankings should be evident regardless of perspective. Accordingly, we compared the standard deviations from the three rankings between the young and old generation for each cultural group. Paired comparison $t$-tests showed that older Itza' had reliably smaller standard deviation for personal $(t(21)=2.82, p<.01)$ and arux $(t(21)=3.77, p<.01)$ rankings and marginally smaller standard deviation for God's ranking $(t(21)=1.96, p=.06)$. Ladinos differed only in personal rankings, with the older Ladinos having smaller standard deviation $(t(21)=3.1, p<.01)$. These data are consistent with knowledge loss.

Itza' estimates of God's preferences also suggest a value shift. Consider the younger generation rankings from God's perspective, especially for two important trees, chicle and Ceiba (Guatemala's national symbol and the traditional Maya 'Tree of life'). Both were near the top for older Itza', but are much lower for younger Itza'. Changes in rankings from the perspective of the arux/duende are also informative. For both Itza' and Ladinos the water vine goes from a high ranking among older generations to below average ranking for youngsters. As noted earlier, allspice (Pimenta diocia) and the water vine (Vitis tiliifolia) are directly connected to the cultural representation of the arux/duende, which like the smell of the former and like to drink from the latter. Ranking changes suggest that the older Itza' conception of the arux as a concrete entity is being replaced by a more abstract notion that resembles the Ladino's duende.

\section{Follow-up studies}

To explore the generality of these striking changes, we ran the ranking task with two additional samples: (1) essentially the same twelve Itza participants interviewed two years earlier (for re-test reliability) and (2) ten Itza' men who were still engaged in agro-forestry for their primary livelihood. Both subsamples produced results essentially identical to those already reported. Correlations between the rankings of the old sample with the two new samples were as follows: personal values $\left(r_{1}(20)=.83\right.$, $\left.r_{2}(20)=.79, p<.05\right)$, God $\left(r_{1}(20)=.81, p<.05 ; r_{2}(20)=.34, p=.12\right)$, and arux $\left(r_{1}(20)=.47, r_{2}(20)=.53\right.$, ps $\left.<.05\right)$. Given that different researchers conducted this round of interviews, the pattern of results appears robust.

We also re-interviewed one of the Itza' elders who had been part of our studies more than ten years earlier. He is considered to be one of the two leading experts on the forest (the other was his deceased uncle). We asked for personal and arux rank orderings. His personal value rankings coincided with those he had produced the previous decade $(r(20)=.81, p<.05)$ but the ranking for the arux preferences was very different from before $(r(20)=.23, p=.30)$. Furthermore, his new arux rankings agreed substantially with the rankings of the two additional samples $\left(r_{1}(20)=.77, r_{2}(20)=.71, p s<.05\right)$. This strongly suggests that one key factor driving the change in the arux rankings is that both younger and older Itza' believe that the arux have changed. Itza' adults say that the arux are bothered by all the noise associated with development and have retreated deeper into the forest to hide and no longer act as its guardians.

In brief, the value rankings indicate a generalized loss of forest knowledge and diminished interpersonal agreement concerning the relevance of forest plants to people's lives. Associated with this change is a dramatic shift away from understanding the forest spirits as playing a significant role for the Itza'. 


\section{Models of folkecology}

To explore the younger generations' ecological knowledge, we ran the plant-animal interaction task used by Atran et al. (2002). We employed twenty-eight plants and twenty-nine animals, ${ }^{8}$ and for each plant-animal pair we asked informants if the animal interacts with the particular plant. If there was an affirmative answer, we asked what this interaction was. We explicitly asked about each of ten possible relations (uses for shelter, for hiding from predators, for resting, a place to hunt, a source of water, builds nest, nesting materials, eats the fruit, eats the roots, eats the plant). This permits cross-cultural comparisons within an age group, but prohibits cross-generational contrasts.

To estimate agreement, we first collapsed across interaction type, coding a relation as present if any type of interaction was mentioned. Next, the between-informant agreement matrices were fed into a principal component analysis. The consensus for the two generations was estimated separately, and then for each of the four groups. Table 3 summarizes these results.

Collapsing across cultural groups, both older and younger generations show reliable consensus. Competence scores are higher for older Itza' than older Ladinos, but for the younger generation the pattern is reversed. When younger Itza' data are analysed separately they fail to reach consensus (first factor $=27$ per cent of the variance, ratio of first to second factor $=2.3$ ); younger Ladinos do (first factor $=43$ per cent of the variance, ratio of first to second factor $=3.6$ ).

Differences in competence scores reflect differences in agreement with the overall consensus and not necessarily differences in knowledge or expertise. For example, it is possible that younger Itza' show residual agreement apart from the overall consensus or subgroup residual agreement along the lines of gender; however, further analyses revealed that neither of the younger groups displayed reliable residual agreement. ${ }^{9}$ In short, for younger Itza', lower competence scores almost surely reflect loss of ecological knowledge.

\section{Discussion}

Our results show striking generational changes in values, correlated with a change in everyday practices, especially among Itza'. There has been substantial loss of consensus between older and younger Itza'. This reflects changes at two levels: (1) loss of knowledge about the natural world and (2) changes in mental models and sacred values. Younger Itza' resemble younger Ladinos more than older Itza', and the Itza' cosmology and value system appears to be assimilating to the Ladino model. These results mirror changes in younger Itza' way of life and beliefs. We return to these changes in a moment.

Table 3. Variance explained by principal component analysis for the plant-animal interaction task.

\begin{tabular}{llllll}
\hline Groups & $\begin{array}{l}\text { Factor } \\
1(\%)\end{array}$ & $\begin{array}{l}\text { Factor } \\
2(\%)\end{array}$ & $\begin{array}{l}\text { Factor } \\
3(\%)\end{array}$ & $\begin{array}{l}\text { Ratio } \\
\text { Factor 1/ } \\
\text { Factor 2 }\end{array}$ & $\begin{array}{l}\text { Competence } \\
\text { difference }\end{array}$ \\
\hline Itza' old and Ladino old & 34 & 6 & 6 & 5.7 & Itza' higher \\
Itza' young and Ladino young & 30 & 8 & 5 & 3.8 & Ladino higher \\
Itza' old & 45 & 9 & 7 & 5.0 & \\
Ladino old & 32 & 10 & 8 & 3.2 & \\
Itza' young & 27 & 12 & 6 & 2.3 & \\
Ladino young & 43 & 12 & 8 & 3.6 & \\
\hline
\end{tabular}


The younger Ladinos differ from their elders, and older Ladinos tend to resemble older Itza' more than younger Ladinos, especially for the representation of the supernatural entities. How to explain these changes? We know from the social network analyses in Atran et al. (2002) that Ladinos immigrants in La Nueva learned technical knowledge of agro-forestry from the Itza'. They may also have perceived the significant role of the guardian forest spirits in Itza' agro-forestry practices through observation of Itza' rituals and Itza' story-telling (Atran 2001: 168-9; Fréger, Lois, Vapnarsky \& Atran 2010). Older Ladinos may have perceived Itza' as the 'real owner/inhabitants of the forest' (Reina \& Schwartz 1974). They also included Itza' experts in their expert networks (Atran et al. 2002).

Nevertheless, this knowledge transmission process fell far short of high fidelity, and Itza' notions were integrated with Ladino understandings rather than replacing them. For example, older Ladinos readily acquired Itza' notions about how plants help animals but not about animals helping plants. Similarly, the Itza' notion of arux apparently was assimilated to the Ladino conception of the duende. Although both share physical appearance and some of their functions (e.g. trickster), the duende is not a guardian. Such similarities none the less may have facilitated the copying of the Itza' agro-forestry folk model by acknowledging, to some extent, the importance of duende, which is consistent with the internal agreement of old Ladinos concerning the duende rank ordering of plants and the resemblance between spirit rankings of older Itza' and older Ladinos. ${ }^{10}$

But things have changed. New Ladino generations are no longer in close contact with Itza', and the constant arrival of immigrants from other parts of Guatemala and Central America with different cosmological views and values undermines the local adoption of representations of the supernatural entities as guardian spirits.

The continuous flow of immigration, the militant evangelical movement, and the new socio-economic situation tend to favour the importance of God as a supernatural entity, displacing the forest spirits and, indeed, every supernatural entity that does not belong to the Christian pantheon. ${ }^{11}$ Atran and colleagues (Atran 1993; Atran, Lois \& Ucan Ek' 2004; Atran et al. 2002; 2005) showed that customary Itza' understanding of the forest involves a spiritual component. For Itza' of earlier generations, access to the environment is not direct but relies on spiritual guardians, essential intermediaries in people's relationship with the environment. The sanctions that the guardian spirits impose are not a set of defined rules and appear to be loose, especially because the punishment of transgression is not immediate. The non-immediacy of punishment (illness, accident, bad crops, etc.), sometimes spreads out over years, and arguably represents an efficient coercive instrument that carries the idea that one can never escape retribution by supernatural agents. Threats of punishment for norm transgressions may be necessary for reliable co-operation between strangers or acquaintances (Boyd \& Richerson 2002), and supernatural punishment reduces policing costs by promoting self-monitoring (Johnson 2005).

In Itza' folk Catholic cosmology, God is said to have created the earth but is now located at a celestial level and not directly interested in terrestrial affairs. When he created the earth, it is said that he placed local supernatural entities, such as the guardian spirits, to look after particular areas on the earth and control their exploitation. For younger Itza', however, the arux seem irrelevant. One question that arises, then: are the arux dead among younger Itza', or did they vanish into the deep forest as the older people suggest? The arux have lost their importance as guardian spirits and 
Table 4. Changes in the representation and function of the arux/duende among Itza' and Ladinos.

\begin{tabular}{lllllll}
\hline Entity & Group & $\begin{array}{l}\text { Guardian } \\
\text { spirit }\end{array}$ & Helper & Trickster & $\begin{array}{l}\text { Persecuting } \\
\text { lover }\end{array}$ & $\begin{array}{l}\text { Child- } \\
\text { stealer }\end{array}$ \\
\hline $\begin{array}{l}\text { Arux } \\
\text { Duende }\end{array}$ & $\begin{array}{l}\text { Old Itza'-speakers } \\
\text { Young Itza' } \\
\text { Ladinos (old and young) }\end{array}$ & $\checkmark$ & $\checkmark$ & $\checkmark$ & $\checkmark$ & $\checkmark$ \\
\hline
\end{tabular}

helpers for the younger Itza', yet they have not altogether disappeared. Nowadays, encounters (even visual encounters) with the arux sometimes still occur in the forest and within the village (but much less than before and most often in thickly vegetated gullies that are difficult to access). But their functions have been largely reduced to the role of trickster, persecuting lover, and child-stealer. Ethnographical data indicate that almost every inhabitant of San José has had a personal experience with an arux or knows someone in his social network who has. Among the Ladinos, these functions are also recognized, even if encounters are more rare among the inhabitants of La Nueva. Interestingly, the arux did not change appearance among the young Itza', and descriptions are congruent with the old Itza' image of arux. But, with the shift to Spanish, the arux are now known as 'duende' among younger Itza', and have no identifiable function as guardian spirits. Table 4 summarizes these changes.

Older Itza' often say that the younger generation seems disinterested in knowledge of the forest and the Itza' language. This rupture in knowledge transmission is attributed by older Itza' to the idea that 'the younger ones did not ask for learning'. Younger Itza' say that 'elders never teach them'. These justifications are consistent with the customary notions of knowledge transmission as a process of apprenticeship, where the learner has to show interest in learning and the elder has to accept entering in this relation as instructor. But the rupture remains.

The shift in cosmology is visible not only in value rankings, but also in the younger Itza' justifications concerning the necessity of protecting the environment, often expressed in NGO discourse and Western representations. For example, people should protect trees because 'trees are essential for purifying air', a form of justification foreign to Itza' cosmology and clearly derivative of the large-scale conservation push in the 1990 around the theme that the rainforest is the oxygen generator of the planet.

Finally, the shift in how supernatural entities are represented has also favoured a change towards a new, more Western representation of God. This perspective favours humans over plants and animals, unhinging humans from a complex system of ecological interrelationships that includes supernatural entities (see Figure 1). Younger Itza' and Ladinos portray God's role in this system thus: 'He is the one who gave the earth to people to exploit it'. This representation of God encourages a bare-bones (monetized) utilitarian conception of the environment: people should make money exploiting the forest (in particular cash-values trees) to live better in a material world with God's blessing.

As noted by Steinberg (2002) for Belizean Mopan facing evangelical conversion, changes in religious values influence the use of plants and natural resources. Among Itza', copal resin and allspice are still available but not used in the new Catholic practices. The ceiba tree's cosmological importance has also faded: once the symbol of 


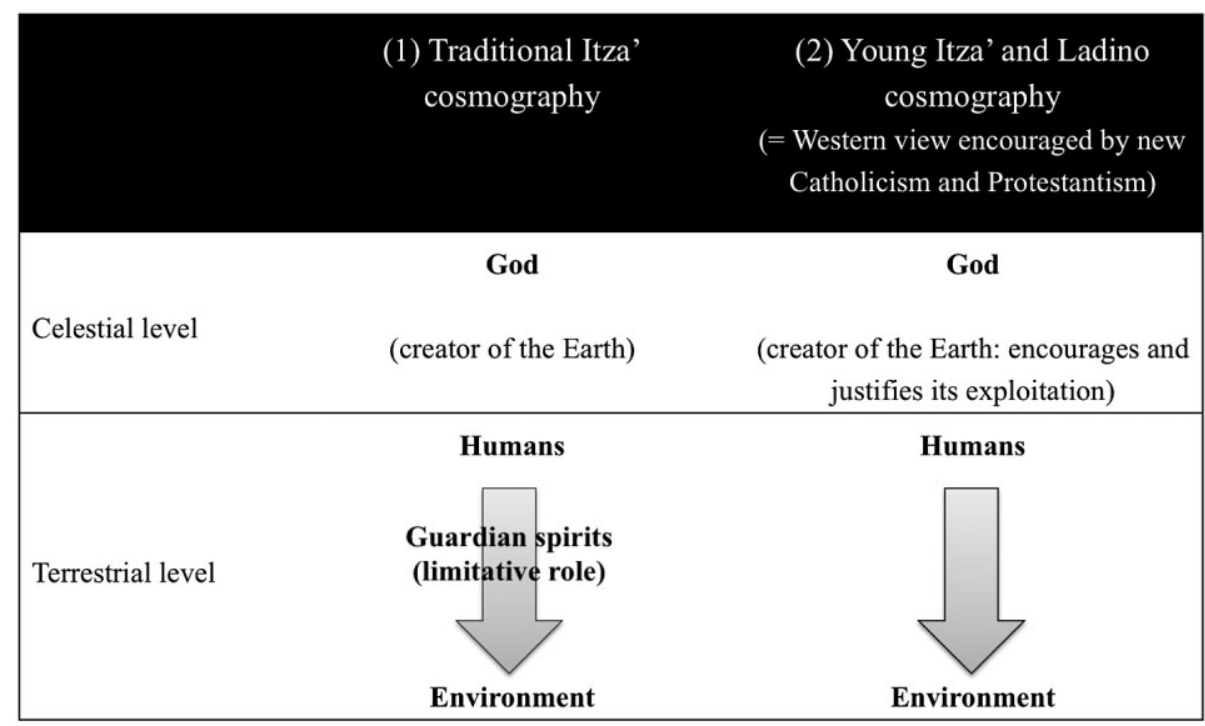

Figure 1. Transformation of cosmography and view of environment exploitation in relation to supernatural entities.

the centre of the earth and refuge of the supernatural Ix Tabay, it is now important only as a national emblem.

\section{Conclusions}

We have described dramatic changes in the mental models and agro-forestry practices of two groups living in the same vicinity: native Itza' Maya and immigrant Ladinos. The older Itza' generation relied on a mental model of the forest regulated by the local guardian spirits, the arux. This nonhuman component reinforced an ecologically centred system of conceptualizing the environment. New forms of forest exploitation exclude spiritual components. Returning to Descola's (2013) typology, we see a shift from an analogism-type relationship maintained by older Itza', of subjectively intimate conceptual and emotional ties between people and their surrounding environment, to a naturalism-type relationship, of depersonalized and objectified relations with the natural environment among the younger Itza' and the Ladinos.

Formerly adaptive behaviours may become maladaptive, as with Itza' conservation practices under Petén's current depredatory conditions. By undertaking costly commitments to preserve the forest, Itza' make it easier for new immigrants to exploit it. In this sense, Itza' may be subsidizing their own cultural extinction. Younger Itza' appear to be abandoning this subsidy, levelling the playing field with immigrants but now also contributing to the demise of the forest commons.

Older Itza' used to say that the spirits of the forest did not disappear; they just withdrew from the town and its loud music and lights, to take shelter deep within the Petén forest (or what is left of it). Older Itza' are now disappearing, along with their language and beliefs. The knowledge of sustainable use of the forest is still available, but newcomers do not believe in the guardian spirits. Even younger generation Itza' who want to believe fear that there will soon be no elders left to tell them what to watch for. 
Instead, they choose to follow a new God who should lead them to material happiness, but, with the end of the forest in view, one can ask: for how long?

\title{
Epilogue
}

In a final follow-up to this study, we interviewed a number of younger and older Itza' in January 2013 on what they believed to be the significance of the arux. The overriding sentiment was resignation at their loss as harbinger of the end of Itza' and their forest world. For example:

\begin{abstract}
The arux have fled into the deep forest ('big forest', noj k'aax) and will not come back and will almost never show themselves in the town because they are afraid of the people who are not afraid of them - people who only make noise and do not care for the forest. And the young people do not want to learn the [Itza'] language so that people do not understand arux (winik ma' tunna'atik arux) and arux do not understand people (arux-ej ma' tunna'atik winik) (Don Nicholas Zacal, 91 years old).
\end{abstract}

The arux, there are still some. Last Sunday my sister saw one in the gully between Julio Tut's house and Don Modesto's. But there are few, even in the forest there are few because there is little forest left. This tells us that we are near the end of our time, the second time. The first time ended with Tikal, Mirador, and the finishing of the Great People (nojoch winik-oo') and the coming of God (dyoos [the European Jesus Christ]), and the second cycle will end with the finishing of the Itza', the forest, and the arux. What the third cycle will bring, I don't know, but it will bring even smaller people and animals and trees, or maybe none (Don Genaro Zacal, 61 years old, the last renowned Itza' shaman, aj-tz'äkyaj).

The arux are part of our [Itza'] language, our culture and our nature (nuestra naturaleza). And only if we preserve our language, our culture, and our nature can the arux exist. I don't know if we can, I don't know if they [the $\operatorname{arux}$ ] can, I don't believe so. But without them, without our history, we [Itza'] are nothing (somos nadie) (Juan Manuel Chayax, 31 years old).

\section{NOTES}

We thank the people of San José and La Nueva for their gracious reception and collaboration. We would also acknowledge Edilberto Ucan Ek' and Reginaldo Chayax for their collaboration on this article. This work was supported by the Fyssen Foundation (Le Guen), NSF grant SES 0962185 and AFOSR grant FA9550-10C-0109 (Atran and Medin).

${ }^{1}$ A mental model represents one possibility, capturing what is common to all the different ways in which the possibility may occur.

${ }^{2}$ Justification for the choice of the plants and animals can be found in Atran et al. (2002: 427 n. 9).

${ }^{3}$ The same process is at stake among the Yucatec Maya (see Hanks 1990 for a general analysis, and Le Guen 2005 for an example with the 'evil winds').

${ }^{4}$ Don Domingo Chayax Suntecún was a prioste ('sacristan'). His role in San José was actually quite special and not traditional, as he took over the vestigial ritual functions of the whole town and began adapting them in various ways (sometimes incorporating Q'eqchi ceremonies). He was universally respected in San José as the collective ritual master.

${ }^{5}$ Although we are speaking somewhat informally here when we say that there is a consensus, there is a mathematical theory behind these statements.

${ }^{6}$ Two other rankings were also collected, but they are not relevant for the present article. In these other rankings, participants were asked to rank the plants as the people from the neighbouring village would rank them. This first inferred ranking for other humans made the task more conceivable and concrete and allowed realistic answers for less concrete entities that are God or the arux/duende.

${ }^{7}$ More specifically, CCM assumes widely shared information is reflected in a high concordance, or 'cultural consensus', among individuals. We used principal component analysis (a close relative to classical factor analysis) to determine if a single underlying model holds for all informants from a given population: a strong consensus exists if: (1) the ratio of the latent root of the first to the second factor is high; (2) the first eigenvalue accounts for a large portion of the variance; and (3) all individual first factor scores are positive and relatively high. If this is the case, then the structure of the agreement can be explained by a single-factor 
solution, the 'consensual model'. In this case, first factor scores represent the agreement of an individual with this consensual model. If there is a generalized loss of knowledge about the forest, then we might expect to see a loss of consensus on value rankings from each of the perspectives. Selective loss of consensus for one or more perspectives would suggest a more subtle change in understandings of the forest. Of course, consensual rankings may remain strong but shift across generations.

${ }^{8}$ The full list of plants and animals can be found in Atran et al. (1999).

${ }^{9}$ Residual agreement reflects systematic differences in knowledge that are not shared by the whole community, but is related to other factors such as occupation, gender, and social or expert networks (see Medin, Lynch, Coley \& Atran 1997 for an example). If young Itza' and young Ladinos had different patterns of residual agreements, then a comparison of competence scores would not necessarily implicate real differences in expertise.

${ }^{10}$ This explanation is not only based on extrapolation. Some documented examples of long contact between immigrant Ladino populations and Maya (native Itza’ Maya from the Petén but also Yucatec Maya immigrants) haveled to religious knowledge transmission. Schwartz (1990) mentions the example of a rain-making ceremony long after the Itza' of San José had abandoned this practice (Atran 1993: 693; Reina 1961).

${ }^{11}$ Steinberg (2002), for instance, discusses the impact of religious changes in a case study among the Mopan of Belize (culturally and linguistically related to the Itza') where new Protestant values dramatically influenced ritual practices but also environmental and agro-forestry practices (such as beekeeping and maize farming).

\section{REFERENCES}

Adams, R. \& A. Rubel 1967. Sickness and social relations. In Handbook of Middle American Indians (ed.) R. Wauchope, 333-57. Austin: University of Texas Press.

Atran, S. 1993. Itza Maya tropical agro-forestry. Current Anthropology 34, 633-700. 1995. Classifying nature across cultures. In Invitation to Cognitive Science, vol. 3: Thinking (ed.) D. Osherson \& E. Smith, 131-74. Cambridge, Mass.: MIT Press.

1998. Folkbiology and the anthropology of science: cognitive universals and cultural particulars. Behavioral and Brain Sciences 21, 547-609.

2001. The vanishing landscape of the Petén Maya Lowlands: people, plants, animals, places, words and spirits. In On biocultural diversity: linking language, knowledge, and the environment (ed.) L. Maffi, 157-74. Washington, D.C.: Smithsonian Institution Press.

\& J. Henrich 2010. The evolution of religion: how cognitive by-products, adaptive learning heuristics, ritual displays, and group competition generate deep commitments to prosocial religions. Biological Theory 5, 18-30.

-, X. Lois \& E. Ucan EK' 2004. Plants of the Peten Itza’ Maya: Plantas De Los Maya Itza' Del Peten (University of Michigan Memoirs of the Museum of Anthropology 38). Ann Arbor: Museum of Anthropology University of Michigan.

$-\&$ D.L. MEDIN 2008. The native mind and the cultural construction of nature. Cambridge, Mass.: MIT Press.

- \& N. Ross 2004. Evolution and devolution of knowledge: A tale of two biologies. Journal of the Royal Anthropological Institute (NS) 10, 395-420.

$\longrightarrow,-2005$. The cultural mind: environmental decision making and cultural modeling within and across cultures. Psychological Review 112, 744-76.

, E. Lynch, J. Coley, E. UCAn EK' \& V. VAPNARSKy 1999. Folkecology and commons management in the Maya Lowlands. In Proceedings of the National Academy of Sciences USA 96, 7598-603. , V. VAPNARSKY, E. UCAN EK' et al. 2002. Folkecology, cultural epidemiology, and the spirit of the commons: a garden experiment in the Maya Lowlands, 1991-2001. Current Anthropology 43, 421-50.

Beller, S., A. Bender \& D.L. Medin 2012. Should anthropology be part of cognitive science? Topics in Cognitive Science 4, 342-53.

Bender, A., S. Beller \& D.L. Medin 2012. Turning tides: prospects for more diversity in cognitive science. Topics in Cognitive Science 4, 462-6.

Berlin, B. 1992. Ethnobiological classification. Princeton: University Press.

BIRD-DAVID, N. 1999. 'Animism' revisited: personhood, environment, and relational epistemology. Current Anthropology 40, S67-S91.

Boyd, R. \& P.J. Richerson 2002. Group beneficial norms can spread rapidly in a structured population. Journal of Theoretical Biology 215, 287-96. 
Boyer, P. 1996. What makes anthropomorphism natural: intuitive ontology and cultural representations. Journal of the Royal Anthropological Institute (N.S.) 2, 1-15.

Brigadas Internacionales de Paz 2007. Boletín especial: El Petén, 7 April (available on-line: http:// www.guatemalanetz.ch/es/Documenti/PBI-Bulletin-Peten-es.pdf, accessed 19 August 2013).

Charnley, S. \& W.H. Durham 2010. Anthropology and environmental policy: what counts? American Anthropologist 112, 397-415.

Chayax Huex, R., F. Tzul Collí, C. Gomez Caal \& S. Gretzinger 1998. The Bio-Itza Reserve: history of an indigenous effort to conserve the Itza Maya community of San José, El Petén, Guatemala. In Timber, tourists, and temples: conservation and development in the Maya Forest of Belize, Guatemala, and Mexico (ed.) R.B. Primack, 317-26. Washington, D.C.: Island Press.

Conen, E. 2010. Anthropology of knowledge. Journal of the Royal Anthropological Institute (N.S.) Special Issue: Making knowledge (ed.) T.H.J. Marchand, S193-202.

Contreras, G. 2012. Brigada contra narco para proteger Petén. Prensa Libre, 7 July (available on-line: http://www.prensalibre.com/noticias/Brigada-narco-proteger-Peten_o_732526772.html, accessed 19 August 2013).

Descola, P. 2011. L'écologie des autres: l'anthropologie et la question de la nature. Versailles: Quae éditions.

2013. Beyond nature and culture. Chicago: University Press.

Diamond, J. \& D.K. Bishop 1999. Ethno-ornithology of the Ketengban people. In Folkbiology (eds) D.L. Medin \& S. Atran, 17-46. Cambridge, Mass.: MIT Press.

Dugelby, B. 1998. Mecanismos gubernamentales y tradicionales que norman la extracción del látex del chicle en El Petén Guatemala. In La Selva Maya (eds) R.B. Primack, D. Bray, H.A. Galletti \& I. Ponciano, 197-220. Mexico D.F.: Conservación y Desarrollo, Siglo XXI Editores.

Frazer, J.G. 1922. The golden bough: a study in magic and religion. New York: Macmillan.

Fréger, F., X. Lois, V. VApnarsky \& S. Atran 2010. ITZA': Memorias Mayas. Mexico City: UNAM.

Garrard-Burnett, V. 1998. Protestantism in Guatemala: living in the New Jerusalem. Austin: University of Texas Press.

Gellner, E. 1963. Nature and society in social anthropology. Philosophical Studies 30, 236-51.

Goodman, L.A. 1961. Snowball sampling. Annals of Mathematical Statistics 32, 148-70.

Goody, E.N. 1995. Social intelligence and prayer as dialogue. In Social intelligence and interaction (ed.) E. Goody, 206-20. Cambridge: University Press.

Grandia, L. 2000. ¿Cuántas personas quiere usted que vivan en Petén? In Encuentro internacional de investigadores: nuevas perspectivas de desarrollo sostenible en Petén, 137-58. Guatemala: FLACSO-Guatemala and CONAP.

HANKs, W.F. 1990. Referential practice: language and lived space among the Maya. Chicago: University Press.

Hofling, C.A. 1996. Indigenous linguistic revitalization and outsider interaction: the Itzaj Maya case. Human Organization 55, 108-16.

INGOLD, T. 2010. Footprints through the weather-world: walking, breathing, and knowing. Journal of the Royal Anthropological Institute (N.S.) Special Issue: Making knowledge (ed.) T.H.J. Marchand, S121-39.

James, W. 1905. The varieties of religious experience. New York: Modern Library.

Johnson, D. 2005. God's punishment and public goods. Human Nature - An Interdisciplinary Biological Perspective 16, 410-46.

KATZ, E.G. 2000. Social capital and natural capital: a comparative analysis of land tenure and natural resource management in Guatemala. Land Economics 76, 114-32.

Knight, N., P. Sousa, J.L. Barrett \& S. Atran 2004. Children's attributions of beliefs to humans and God: cross-cultural evidence. Cognitive Science 28, 117-26.

Latour, B. 2004. Politics of nature: how to bring the sciences into democracy (trans. C. Porter). Cambridge, Mass.: Harvard University Press.

Le Guen, O. 2005. Geografía de lo sagrado entre los Mayas Yucatecos de Quintana Roo - configuración del espacio y su aprendizaje entre los niños. Ketzalcalli 2, 54-68.

Lévi-Strauss, C. 1962. La pensée sauvage. Paris: Plon.

Medin, D.L., E. Lynch, J.D. Coley \& S. Atran 1997. Categorization and reasoning among tree experts: do all roads lead to Rome? Cognitive Psychology 32, 49-96.

Moran, E.F. 2007. Human adaptability: an introduction to ecological anthropology (Third edition). Boulder, Colo.: Westview.

Nabhan, G. \& S. St Antoine 1993. The loss of floral and faunal story: the extinction of experience. In The biophilia hypothesis (eds) S.R. Kellert \& E.O. Wilson, 229-50. Washington, D.C.: Island Press. 
Reina, R.E. 1961. The abandonment of primicias by Itza of San José and Socotz, British Honduras. In Tikal Report 10. Philadelphia: Philadelphia University Museum.

\& N.B. Schwartz 1974. The structural context of religious conversion in Petén, Guatemala: status, community, and multicommunity. American Ethnologist 1, 157-91.

Romney, A.K., S.C. Weller \& W.H. BAtchelder 1986. Culture as consensus: a theory of culture and informant accuracy. American Anthropologist 88, 313-38.

Sснмidt, B. 2010. Ranchers and drug barons threaten rain forest. New York Times, 17 July.

Schwartz, N.B. 1987. Colonization of Northern Guatemala: the Petén. Journal of Anthropological Research 43, $163-83$.

1990. Forest society: a social history of Petén, Guatemala. Philadelphia: University of Pennsylvania Press.

Selleron, G. 2004. Analyse d'un front pionnier par images satellitales multidates de 1987 à 2002: le cas du nord-ouest du Petén (Guatemala). Cybergeo: European Journal of Geography, Environment, Nature, Landscape, document 290 (available on-line: http://cybergeo.revues.org/3280, accessed 23 August 2013).

Sperber, D. \& D. Wilson 2004. Relevance: communication and cognition (Second edition). Oxford: WileyBlackwell.

Spoon, J. 2012. Tourism, persistence, and change: Sherpa spirituality and place in Sagarmatha (Mount Everest) National Park and Buffer Zone, Nepal. Journal of Ecological Anthropology 15, 41-57.

SteinberG, M.K. 2002. The second conquest: religious conversion and the erosion of the cultural ecological core among the Mopan Maya. Journal of Cultural Geography 20, 91-105.

VAYDA, A.P. 2009. Explaining human actions and environmental changes. Lanham, Md: AltaMira Press.

Viveiros De CAStro, E. 1992. From the enemy's point of view: humanity and divinity in an Amazonian society (trans. C.V. Howard). Chicago: University Press.

2004. Exchanging perspectives: the transformation of objects into subjects in Amerindian ontologies. Common Knowledge 10, 463-84.

Vosniadou, S. \& A. Ortony 1989. Similarity and analogical reasoning. Cambridge: University Press.

Wester, L. \& S. YongVanit 1995. Biological diversity and community lore in Northwestern Thailand. Journal of Ethnobiology 15, 71-87.

Whitehouse, H. \& J. Laidlaw (eds) 2007. Religion, anthropology, and cognitive science. Durham, N.C.: Carolina Academic Press.

Whitten, A. (ed.) 1991. Natural theories of mind: evolution, development and simulation of everyday mindreading. Oxford: Blackwell.

Willems, E. 1967. Followers of the new faith: culture change and the rise of Protestantism in Brazil and Chile. Nashville: Vanderbilt University Press.

Wilson, R. 1995. Maya Resurgence in Guatemala: Q'eqchi' Experiences. Norman: University of Oklahoma Press.

ZeNT, S. 2001. Acculturation and ethnobotanical knowledge loss among the Piaroa of Venezuela: demonstration of a quantitative method for the empirical study of TEK change. In On biocultural diversity: linking language, knowledge and the environment (ed.) L. Maffi, 190-211. Washington, D.C.: Smithsonian Institution Press.

\section{L'expérience du jardin revisité : changements intergénérationnels dans la perception et le maniement de l'environnement dans les terres-basses mayas du Guatemala}

Résumé

Le présent article rend compte d'une analyse ethnographique et expérimentale du changement intergénérationnel chez les Mayas Itzá indigènes et les immigrés Ladinos dans la forêt tropicale du Petén (Guatemala), relatif à la conception des relations écologiques entre plantes, animaux et humains ainsi qu'au rôle des entités surnaturelles tel qu'il est perçu dans le maintien de ces relations. Nos résultats montrent des changements profonds, tant dans la compréhension des relations écologiques que dans la conception du rôle des esprits de la forêt. Les notions mayaitzá associées aux esprits de la forêt (ou arux) sont maintenant souvent mêlées à celles des Ladinos et l'arux n'est plus perçu comme un esprit gardien de la forêt de manière fiable. Ces changements sont corrélés à une évolution dans les valeurs individuelles concernant la forêt et on note un transfert des préférences de la protection des arbres écologiquement centraux vers celle des arbres à forte valeur marchande. D’une façon générale, nous décrivons comment les changements économiques, démographiques et sociaux sont associés à l'altération d'un système de 
croyances et de comportements qui autrefois promouvait une exploitation agro-forestière durable. Ces changements sont favorisés par l'accès illimité aux ressources naturelles.

Olivier Le Guen is Professor of Linguistic Anthropology at CIESAS (Mexico City). His research focuses on the relation between culture, language, and cognition. He works among the Yucatec Mayas on issues like the conception of space and time, and he is also interested in describing forms of multimodal communication among the Mayas.

Centro de Investigaciones y Estudios Superiores en Antropología Social (CIESAS), Linguistics, Juarez 87, Federal District, Tlalpan, 14000 Mexico.ompleguen@gmail.com

Rumen Iliev is a postdoctoral researcher at the Ford School of Public Policy and an ARTIS fellow. His main line of work concerns the overlap between cognition, morality, and culture. He has conducted research on the cognitive properties of sacred values, the perception of causality in moral reasoning, and context effects in moral choice.

riliev@umich.edu

Ximena Lois has a Ph.D. in Linguistics from the University of Paris and is a specialist in Mayan and Romance languages. She is a Research Associate at the University of Michigan's Institute for Social Research and at the Institut Jean Nicod in Paris. She conducted several years of fieldwork among the Itza' in Guatemala.

ximenal@umich.edu

Scott Atran is Research Director in Anthropology at France's National Centre for Scientific Research, Institut Jean Nicod-École Normale Supérieure, in Paris. He is also Presidential Scholar, John Jay College of Criminal Justice, New York; Adjunct Professor Psychology and Public Policy, University of Michigan; and Director of Research, ARTIS Research.

satran@umich.edu

Douglas L. Medin is the Louis Menk Professor of Psychology at Northwestern University, with a joint appointment in the School of Education and Social Policy. His research interests include science learning in and out of the classroom, decision-making, categorization and reasoning, and culture and cognition.

medin@northwestern.edu 